Vol 1. No 1. Agustus 2021, e-ISSN : 2807-1808 | P-ISSN : 2807-2294

\title{
PENINGKATAN MOTIVASI DAN PRESTASI BELAJAR SISWA DALAM PEMBELAJARAN PPKN MELALUI METODE GROUP INVESTIGATION DI KELAS XI-APHP 2 SMKN 1 CANGKRINGAN SLEMAN
}

\author{
ENI LESTARI \\ SMKN 1 Cangkringan Sleman \\ e-mail: enys.enlles@gmail.com
}

\begin{abstract}
ABSTRAK
Penelitian ini dilatarbelakangi oleh rendahnya motivasi dan prestasi belajar PPKn siswa kelas XI APHP 2 SMKN 1 Cangkringan dibanding dengan kelas XI lainnya. Hal ini diduga disebabkan oleh pola pembelajaran yang dilakukan guru masih membuat siswa kurang aktif dalam proses pembelajaran serta kurangnya variasi model dalam pembelajaran PPKn. Hasil penelitian ini menunjukkan terjadinya peningkatan nilai rata-rata setiap pengamatan siklus. Penilaian motivasi belajar mengalami peningkatan rata-rata skor kelas dari siklus I adalah 1.67 predikat C (Cukup), siklus II adalah 2.72 predikat B (Baik) dan siklus III adalah 2.83 predikat B (Baik) dan untuk penilaian rata-rata kelas uji kompetensi I diperoleh 45.52, uji kompetensi II diperoleh 79.41, dan uji kompetensi III 81.75. Dari hasil wawancara dengan guru dan siswa juga mengatakan proses pembelajaran dengan menggunakan Group Investigation lebih menyenangkan. Setelah melaksanakan penelitian tindakan kelas, disimpulkan bahwa model pembelajaran Group Investigation, dapat meningkatkan motivasi belajar dan prestasi belajar PPKn siswa kelas XI APHP 2.
\end{abstract}

Kata Kunci: Metode Pembelajaran, Group Investigation, Motivasi Belajar

\section{PENDAHULUAN}

Dalam UU RI No. 20 Tahun 2003 tentang Sistem Pendidikan Nasional, pasal 1 menjelaskan pendidikan adalah usaha sadar dan terencana untuk mewujudkan suasana belajar dan proses pembelajaran agar peserta didik secara aktif mengembangkan potensi dirinya untuk memiliki kekuatan spiritual keagamaan, pengendalian diri, kepribadian, kecerdasan, akhlak mulia, serta keterampilan yang diperlukan dirinya, masyarakat, bangsa dan negara (Departemen Pendidikan Nasional, 2014). Peran pendidikan sendiri adalah dapat meningkatkan kualitas sumber daya manusia, mewujudkan kesejahteraan umum dan mencerdaskan kehidupan bangsa.

Masyarakat yang berpendidikan tentu memiliki kualitas hidup yang lebih baik dari pada yang tidak berpendidikan, kesejahteraan batiniah dan lahiriah juga mempengaruhinya. Bangsa yang cerdas pasti masyarakatnya memiliki sumber daya manusia yang berkualitas juga. Untuk itu belajar sangat penting bagi diri sendiri dan lingkungan sekitar. Pentingnya belajar untuk belajar (learning to learn) menumbuhkan sikap terbuka terhadap adanya perubahan dan tantangan globalisasi yang semakin modern dan menantang.

Mata pelajaran Pendidikan Pancasila dan Kewarganegaraan merupakan salah satu mata pelajaran yang wajib disampaikan kepada siswa. Diharapkan setelah mengikuti pelajaran Pendidikan Pancasila dan Kewarganegaraan, siswa menjadi lebih dan mampu melaksanakan hak-hak dan kewajiban unuk menjadi warga negara yang cerdas, terampil, dan berkarakter yang diamanatkan oleh Pancasila dan UUD 1945 (Cholisin, BNSP, Standard Isi Mata Pelajaran Pendidikan Kewarganegaraan).

Proses pembelajaran Pendidikan Pancasila dan Kewarganegaraan yang dilakukan oleh guru selama ini dilakukan secara konvensional dengan menggunakan metode ceramah yang monoton dan mengarah kepada hafalan. Guru memulai pelajaran dengan menjelaskan materi, kemudian dilanjutkan dengan latihan-latihan soal yang ada di buku paket. Guru jarang menggunakan dunia nyata sebagai suatu konteks bagi siswa untuk belajar berpikir kritis dan terampil dalam memecahkan masalah untuk memperoleh konsep atau pengetahuan. Guru jarang memberi tugas kepada siswa secara individual atau kelompok untuk melakukan 
pembahasan terhadap materi yang memungkinkan mereka menginterprestasikan dan menjelaskan fenomena dalam kehidupan nyata sehari-hari.

Untuk mencapai motivasi dan prestasi belajar yang optimal diperlukan strategi pembelajaran yang tepat agar tujuan dapat terwujud. Strategi pembelajaran merupakan perencanaan yang berisi tentang rangkaian kegiatan yang didesain untuk mencapai tujuan pembelajaran (Sanjaya,2006:126). Banyak sekali strategi pembelajaran yang dapat dipilih oleh seorang guru dalam proses belajar mengajar, seperti pembelajaran berdasarkan masalah, pembelajaran kooperatif, pembelajaran kontekstual, pembelajaran dengan penemuan dan lain sebagainya. Metode-metode pembelajaran ini diklasifikasikan berdasarkan tujuan pembelajarannya, pola urutannya dan sifat lingkungan belajarnya.

Salah satu faktor yang mempengaruhi prestasi belajar PPKn siswa adalah metode mengajar guru. Metode mengajar guru adalah cara yang dilakukan oleh guru dalam proses belajar mengajar sehingga dapat diperoleh hasil yang optimal. Setiap guru diharapkan dapat menggunakan metode yang bervariasi dan tepat untuk diterapkan didalam kelas yang terdapat bermacam-macam siswa dengan karakteristik yang berbeda-beda. Metode mengajar guru di SMK N 1 Cangkringan masih kurang karena penggunaan metode mengajar guru yang selalu monoton, kurang bervariasi sehingga siswa merasa cepat bosan dalam mengikuti pelajaran. Jika guru mau menggunakan metode mengajar yang bervariasi, siswa akan menjadi termotivasi dalam mengikuti pelajaran sehingga dapat meningkatkan prestasi belajar PPKn.

Pembelajaran PPKn di sekolah-sekolah khususnya di SMK Negeri 1 Cangkringan di kelas XI APHP 2, masih belum mencerminkan misi dan tujuan dari mata pelajaran PPKn. Hal ini tercermin dari model pembelajaran yang digunakan oleh guru, bahwa dalam proses pembelajaran guru cenderung mentrasfer ilmu yang ada dipikirannya ke pikiran siswa. Berdasarkan observasi awal dan wawancara dengan guru bidang studi PPKn tingkat aktivitas dan hasil belajar siswa yang dicapai masih kurang pada kelas XI APHP 2 khususnya pada mata pelajaran PPKn. Permasalahan yang ditemukan adalah hasil belajar siswa kurang maksimal yang diperoleh dari data awal kelas XI APHP 2 yaitu masih terdapat 3 siswa dari 29 siswa atau $10,35 \%$ siswa yang belum mencapai Kriteria Ketuntasan Minimal (KKM) yaitu 2,66. Siswa memiliki motivasi belajar yang berbeda XI APHP 2 cenderung rendah. Hal ini dapat diketahui dari sikap siswa ketika kegiatan pembelajaran berlangsung. Siswa cenderung kurang memperhatikan dan masih ada yang berbicara sendiri pada saat guru memberikan pelajaran. Keaktifan atau antusiasme belajar kurang karena siswa menganggap pelajaran PPKn sulit dipahami sehingga prestasi belajarnya rendah. Metode mengajar guru tentu akan menentukan siswa tertarik atau tidak untuk mengikuti pelajaran dengan sungguh- sungguh atau bermalasmalasan untuk mengikuti pelajaran, bahkan mungkin asyik sendiri dengan temannya. Aktivitas siswa yang tergolong rendah dengan pencapaian tingkat keberhasilan yang tergolong dalam kriteria kurang aktif, kondisi kelas yang pasif, siswa tidak bersemangat untuk belajar dan siswa kurang termotivasi dalam menekuni dan mendalami pembelajaran PPKn.

Berdasarkan hal tersebut, perlu adanya model dalam strategi pembelajaran yang lebih mengaktifkan siswa serta dapat mengembangkan daya nalarnya. Semua model pembelajaran ditandai adanya struktur tugas, struktur tujuan dan struktur penghargaan (reward). Kemudian Slavin, (2003:16) mengemukakan bentuk-bentuk model pembelajaran kooperatif tipe Group Investigation diantaranya: (1) Devisi Tim Siswa Berprestasi (Student Team Achievement Division), (2) Tim Turnamen Bermain (Team Game Turnament) (3) Tim Individual Berbantuan (Team Asisted Individualization) (4) Gergaji Silang (Jigsaw) (5) Investigasi Kelompok (Group Investigation) (6) Belajar bersama (Learning Together).

Dari bentuk-bentuk pembelajaran kooperatif yang disebutkan, antara guru dengan peneliti mendiskusikan model pembelajaran yang dianggap tepat dengan kelas XI APHP 2. Maka guru dan peneliti menganggap model pembelajaran kooperatif tipe Group Investigation dapat diterapkan dalam penelitian ini, karena model pembelajaran kooperatif tipe Group Investigation lebih terfokus pada pemecahan masalah, membuat seluruh kelompok aktif dan 
akan timbul rasa keberanian dalam mengemukakan pendapat serta menyampaikan informasi kepada teman-temannya.

Kelebihan dari model pembelajaran kooperatif tipe Group Investigation diantaranya dapat melatih kemampuan siswa dalam berdiskusi, fungsi ingatan siswa menjadi lebih aktif, lebih bersemangat dan berani dalam mengemukakan pendapat, dapat menimbulkan motivasi siswa, dapat meningkatkan kerja keras siswa, lebih giat, dan lebih termotivasi dalam belajar.

\section{METODE PENELITIAN}

Penelitian ini menggunakan Penelitian Tindakan Kelas (PTK), tujuan utama dari PTK adalah untuk memperbaiki/meningkatkan praktek pembelajaran secara berkesinambungan, sedangkan tujuan penyertaannya adalah menumbuhkan budaya meneliti di kalangan guru.

Sesuai dengan jenis penelitian yang dipilih, yaitu penelitian tindakan, maka penelitian ini menggunakan model penelitian tindakan dari Kemmis dan Taggart, yaitu berbentuk spiral dari sklus yang satu ke siklus yang berikutnya. Setiap siklus meliputi planning (rencana), action (tindakan), observation (pengamatan), dan reflection (refleksi). Langkah pada siklus berikutnya adalah perencanaan yang sudah direvisi, tindakan, pengamatan, dan refleksi

\section{HASIL DAN PEMBAHASAN}

\section{SIKLUS I}

Sejak dilakukan pra-observasi, guru mata pelajaran dan peneliti sepakat menentukan obyek penelitian berdasarkan pertimbangan faktor keterlaksanaannya proses pembelajaran. Penerapan pembelajaran PPKn pada siklus I melalui pembelajaran tipe Group Investigation adalah:

\section{1) Perencanaan Tindakan Siklus I}

Tahap perencanaan dimulai dengan peneliti dan guru melakukan diskusi kolaborasi dengan mendiskusikan Rencana Pelaksanaan Pembelajaran (RPP) PPKn dan model pembelajaran kooperatif tipe Group Investigation materi pokok Bahtera Keadilan Bangsa Indonesia. Menetapkan kompetensi dasar materi pembelajaran. Menyusun langkah- langkah pembelajaran bersama. Membuat atau menyiapkan media pembelajaran, membuat lembar observasi peserta didik berupa penilaian motivasi belajar siklus I, membuat soal angket berupa tes uji kompetensi I dalam bentuk essay dan kunci jawaban untuk menguji kemampuan peserta didik dalam pembelajaran di pertemuan pertama, menyiapkan bahan untuk diskusi kelompok dan bagaimana membagi kelompok di pertemuan yang kedua dan menyiapkan dukumentasi sebagai pelengkap penelitian. Pertemuan pertama dengan alokasi waktu $2 \times 45$ menit pertemuan dengan metode Group Investigation.

\section{2) Pelaksanaan Tindakan Siklus I}

Kegiatan yang dilakukan oleh guru dan kolaborator dilaksanakan pada hari Senin, 5 dan 12 Maret 2015 pada pukul 07.45 sampai 09.15. Guru memasuki ruang kelas mengucapkan salam dan berdoa kemudian mempersiapkan kelas agar lebih kondusif untuk proses belajar. Kemudian guru melakukan presensi kelas. Guru menjelaskan tujuan pembelajaran hari ini dan menyampaikan peta konsep.

Melaksanakan tes uji kompetensi I dalam bentuk essay yang telah disiapkan guna mengetahui kemampuan awal siswa mengenai pelajaran yang disampaikan. Dengan mengetahui kemampuan awal siswa ini, guru akan dapat menentukan cara penyampaian pelajaran yang akan di tempuhnya nanti dalam pembelajaran PPKn. Dalam materi pembelajaran yang baru Guru mata pelajaran PPKn melaksanakan kegiatan di kelas sesuai dengan desain pembelajaran, dan peneliti melakukan pengamatan serta memberikan arahan, motivasi, dan rangsangan kepada guru yang melakukan tindakan. Menerangkan apa itu pembelajaran dengan metode Group Investigation itu. Guru bidang studi PPKn melaksanakan langkah-langkah pembelajaran sesuai dengan skenario yang telah disepakati bersama peneliti. Selama kegiatan berlangsung peran guru disini melakukan proses belajar mengajar dengan menggunakan metode Group Investigation. 


\section{3) Observasi dan Interpretasi siklus I}

Kegiatan observasi dilakukan peneliti selama kegiatan berlangsung. Tujuan observasi ini adalah untuk mengamati secara sistematis dan komprehesif dengan mengisi lembar penilaian motivasi belajar siklus I dan membuat dokumentasi penelitian. Instrumen yang disiapkan peneliti untuk mengetahui bagaimana proses pembelajaran berlangsung dalam penerapan metode Group Investigation. Peneliti juga memberikan arahan, motivasi, rangsangan kepada guru yang melakukan tindakan, serta mencatat bagaimana keadaan siswa tentang feed back pembelajaran.

\section{4) Analisis dan Refleksi Tindakan Siklus I}

Pada pelaksanaan refleksi, peneliti dan guru melakukan diskusi untuk mengevaluasi kekuatan maupun kelemahan yang ditemukan selama siklus I berlangsung, kemudian hasil refleksi dijadikan acuan dan pertimbangan pelaksanaan tindakan selanjutnya. Hasil refleksi yang dilakukan selama proses pembelajaran siklus I ditemukan bahwa setiap pelaksanaan kegiatan dalam perencanaan pembelajaran dengan alokasi waktu $2 \times 45$ menit dalam seminggu masih dirasa cukup kurang, perlu penambahan waktu. Karena tidak cukup waktu melaksanakan semua tindakan yang direncanakan. Pada pertemuan pertama terlihat guru sudah melaksanakan proses pembelajaran sesuai dengan RPP. Perencanaan pembelajaran sudah sesuai dengan kriteria, tapi masih rendahnya motivasi belajar siswa dalam mengikuti pembelajaran. Sehingga perlu peran guru membuat kondisi kelas yang lebih menyenangkan dan kondusif. Membuat variasi metode pembelajaran, misalnya dengan memberikan contoh pembelajaran yang konkret atau secara gamblang kepada siswa.

\begin{tabular}{|c|c|c|c|}
\hline \multirow[b]{2}{*}{ No } & \multirow[b]{2}{*}{ Indikator } & \multicolumn{2}{|l|}{ Nilai } \\
\hline & & Rata-rata & Predikat \\
\hline 1 & Selalu hadir dan tidak pernah membolos sekolah & 1.97 & $\mathrm{C}$ \\
\hline 2 & $\begin{array}{l}\text { Serius pada saat mengikuti kegiatan pembelajaran } \\
\text { dengan baik }\end{array}$ & 1.62 & C \\
\hline 3 & $\begin{array}{l}\text { Aktif bertanya serta mengajukan pendapat secara } \\
\text { runtut dengan bahasa yang baik dan benar }\end{array}$ & 1.69 & C \\
\hline 4 & $\begin{array}{l}\text { Melaksanakan tugas individu, kelompok dengan } \\
\text { baik dan benar }\end{array}$ & 1.69 & C \\
\hline 5 & $\begin{array}{l}\text { Mampu mempertahankan pendapat dari } \\
\text { permasalahan materi pembelajaran }\end{array}$ & 1.9 & C \\
\hline 6 & $\begin{array}{l}\text { Selalu cepat dalam merespon atau menanggapi } \\
\text { materi pembelajaran yang disajikan }\end{array}$ & 1.69 & C \\
\hline & JUMLAH & 10.03 & \\
\hline & Rata-rata & 1.67 & $\mathrm{C}$ \\
\hline
\end{tabular}

Dari hasil observasi terhadap motivasi belajar siswa Rekayasa Perangkat Lunak 1 siklus I diperoleh rata-rata kelas aspek penilaian selalu hadir dan tidak pernah membolos sekolah adalah 1.97, Serius pada saat mengikuti kegiatan pembelajaran dengan baik memperoleh 1.62, aktif bertanya,serta mengajukan pendapat secara runtut dengan bahasa yang baik dan benar 1.69, melaksanakan tugas individu, kelompok dengan baik dan benar 1.69, mampu mempertahankan pendapat dari permasalahan materi pembelajaran 1.9 dan dapat merespon atau menanggapi materi pembelajaran yang disajikan 1,69. Diperoleh rata-rata 1.67, yang mendapat predikat, dari hasil dikatakan bahwa motivasi siswa dalam belajar memperoleh predikat $\mathrm{C}$ (Cukup), hal ini menunjukkan motivasi belajar siswa dalam siklus I masih dianggap kurang memenuhi penilaian minimal yang diharapkan yaitu B (Baik). Dari hasil penilaian motivasi belajar diperoleh bahwa sebanyak 22 siswa dari 29 siswa memperoleh predikat C (Cukup). Tujuh diantaranya tidak mengikuti kegiatan pembelajaran dikarenakan ijin. 
Pada siklus I, penilaian terhadap motivasi belajar siswa masih sangat rendah dan masih dalam kategori dibawah ketuntasan minimum. Hal ini dikarenakan adanya faktor-faktor yang mempengaruhi motivasi belajar siswa. Banyaknya siswa yang tidak mengikuti proses pembelajaran, kondisi kelas yang masih belum kondusif yang dapat dilihat dari kondisi kelas yang ramai dan banyak siswa yang tidak fokus mengikuti pelajaran PPKn. Disamping itu adanya fasilitas ruang kelas yang belum memadai seperti tidak adanya stop kontak karena dirusak. Kemudian hasil uji kompetensi I yang masih belum sesuai apa yang diharapkan.

Tabel 2. Penilaian Uji Kompetensi I Siswa Kelas XI APHP 2

\begin{tabular}{|l|l|}
\hline Jumlah siswa & 29 \\
\hline Skor tertinggi & 60 \\
\hline Skor terendah & 0 \\
\hline Memenuhi kompetensi & 0 \\
\hline Belum memenuhi kompetensi & 29 \\
\hline Persentase memenuhi kompetensi & $0 \%$ \\
\hline Persentase belum memenuhi kompetensi & $100 \%$ \\
\hline
\end{tabular}

Dari hasil data penilaian uji kompetensi I yang dilakukan peneliti, diperoleh hasil sebanyak $100 \%$ masih mendapat nilai dibawah kompetensi. Kecenderungan nilai yang masih dibawah kompetensi ini didominasi dengan nilai atau angka siswa yang sama. Nilai uji kompetensi I bertujuan untuk mengetahui sejauh mana peserta didik memahami materi yang akan diajarkan. Untuk itu perlu adanya motivasi kepada siswa untuk menyiapkan pembelajaran sebelum pelajaran dimulai. Supaya anak dapat belajar mandiri mempersiapkan segala yang dibutuhkan dalam menghadapi pelajaran.

\section{SIKLUS II}

Penerapan pembelajaran PPKn pada siklus II melalui pembelajaran tipe Group Investigation adalah:

1) Perencanaan Tindakan Siklus II

Peneliti dan guru melakukan rancangan kolaborasi menyusun rancangan kegiatan. Mengadakan diskusi tentang rancangan pembelajaran tahap perencanaan dimulai dengan membuat Rencana Pelaksanaan Pembelajaran (RPP) PPKn dan model pembelajaran kooperatif tipe Group Investigation materi pokok Bahtera Keadilan Bangsa Indonesia. Menyiapkan lembar penilaian motivasi yang kedua, lembar observasi kegiatan diskusi, lembar kinerja presentasi, lembar uji kompetensi II, lembar soal penugasan individu dan dokumentasi.

Adapun perbaikan rancangan untuk siklus II yaitu: guru harus lebih efektif menyampaikan langkah-langkah pembelajaran materi PPKn, guru harus lebih melakukan interaksi dengan siswa, menciptakan kondisi kelas yang lebih kondusif, dan perbaikan tes essay nilai uji kompetensi I berupa tes essay uji kompetesi II, dengan soal yang sama dengan uji kompetensi I.

\section{2) Pelaksanaan Tindakan Siklus II}

Pelaksanaan tindakan pembelajaran pada siklus II dilaksanakan pada tanggal 26 Januari dan 2 Februari 2015. Pada tahap awal kegiatan yang dilakukan oleh guru dan kolaborator yaitu memasuki ruang kelas mengucapkan salam dan berdoa kemudian mempersiapkan kelas agar lebih kondusif untuk proses belajar. Kemudian guru melakukan presensi kelas. Guru menjelaskan tujuan pembelajaran hari ini dan menyampaikan peta konsep.

Pada siklus II ini akan dilaksanakan diskusi kelompok selama 30 menit yang kemudian di presentasikan di depan kelas selama 10 menit. Pelaksanaan dimulai dengan guru membagi siswa menjadi kelompok diskusi yang heterogen dalam jumlah 5-6 orang per kelompok. Kelompok yang sudah ditetapkan dengan topik kajian ditugaskan untuk membuat bahan presentasi dan mempresentasikannya di depan kelompok lain. Berkaitan dengan tugas terstruktur siswa dalam kelompok melakukan proses pengumpulan data dari berbagai 
sumber. Berdasarkan hasil informasi tersebut siswa mengidentifikasi masalah yang timbul, mengasosiasikan atau menganalisis data tersebut yang kemudian dikomunikasikan secara lisan dengan menyajikannya di depan kelas. Kemudian selama proses diskusi dan presentasi, peneliti mengamati dan mencatatnya dalam lembar yang tersedia.

Setelah diskusi selesai, kemudian dilaksanakan tes essay uji kompetensi II sebagai tes perbaikan dari siklus I. Tes berlangsung selama 30 menit dengan 4 buah soal berupa essay. Diakhir pertemuan, guru memberikan tugas individu yang dikumpulkan minggu depan. Tiap individu mengerjakan tugas yang dikerjakan di rumah.

\section{3) Observasi dan Interpretasi siklus II}

Kegiatan pengamatan terhadap tindakan pembelajaran dilakukan saat proses pembelajaran berlangsung. Dari hasilnya diperoleh, selama kegiatan diskusi antar kelompok, kondisi kelas ramai dengan diskusi siswa. Motivasi belajar siswa sedikit meningkat, karena kegiatan diskusi yang menyenangkan. Selama proses presentasi tidak banyak siswa yang aktif berpartisipasi dalam bertanya atau memberi jawaban. Kegiatan tersebut hanya didominasi oleh siswa yang pintar dan pandai berkomunikasi. Kegiatan pengamatan tersebut walaupun tidak secara keseluruhan siswa menjadi aktif, tapi selama proses pembelajaran siswa terlibat dan terjadi interaksi. Dengan demikian proses pembelajaran dengan metode Group Investigation terdapat peningkatan siswa menjadi lebih baik.

4) Analisis dan Refleksi Tindakan Siklus II

Hasil dari analisis dan refleksi yang dilakukan terhadap pembelajaran siklus II ditemukan bahwa setiap tahap pelaksanaan kegiatan dalam pembelajaran perlu merangsang siswa untuk aktif dalam hal bertanya dan memberikan tanggapan. Diperoleh data hasil pengamatan :

Tabel 3. Penilaian Observasi Kegiatan Diskusi Siswa Kelas XI APHP 2

\begin{tabular}{|l|l|l|l|}
\hline $\begin{array}{l}\text { Jumlah } \\
\text { siswa }\end{array}$ & $\begin{array}{l}\text { Nilai } \\
\text { kualitatif }\end{array}$ & $\begin{array}{l}\text { Jumlah } \\
\text { siswa }\end{array}$ & Persentase \\
\hline \multirow{5}{*}{29} & SB & 11 & $37,93 \%$ \\
\cline { 2 - 4 } & B & 17 & $58,62 \%$ \\
\cline { 2 - 4 } & C & 0 & $0 \%$ \\
\cline { 2 - 4 } & K & 0 & $0 \%$ \\
\hline
\end{tabular}

Pada data tabel Penilaian terhadap observasi kegiatan diskusi siswa kelas XI APHP 2 diperoleh data nilai kualitatif siswa yaitu nilai Sangat Baik diperoleh 11 siswa dengan persentase 37,93\%. Nilai Baik didapat oleh 18 siswa dengan jumlah persentase $58,62 \%$. Untuk nilai $\mathrm{C}$ dan $\mathrm{D}$, tidak diperoleh siswa. Tapi satu siswa tidak memenuhi kompetensi, dikarenakan absen sakit.

Tabel 4. Persentase Pencapaian KKM Kegiatan Diskusi Siswa Kelas XI APHP 2

\begin{tabular}{|l|l|}
\hline Jumlah siswa & 29 \\
\hline Siswa yang belum tuntas & 1 \\
\hline Siswa yang sudah tuntas & 28 \\
\hline Presentase belum tuntas & $3,45 \%$ \\
\hline Presentase sudah tuntas & $96,55 \%$ \\
\hline
\end{tabular}

Pada tabel persentase pencapaian KKM terhadap kegiatan diskusi peserta didik diperoleh hasil siswa sudah diatas rata-rata yaitu 96,55\% sudah memenuhi kriteria ketuntasan. Ketuntasan dinilai dari sikap kesopanan, kerja sama, semangat, toleransi, meluruskan penyimpangan, dan menunjukkan sikap terpuji. Dalam hal berpendapat berpikir secara rasional, teliti, jelas, relevan, sistematis dan keaktifan berpendapat. Dari segi bahasa juga sudah jelas, teliti, tepat, menarik dan wajar. Tapi dari satu siswa belum memenuhi kompetensi dikarenakan absen sakit. 
Tabel 5. Penilaian Kinerja Presentasi Siswa Kelas XI APHP 2

\begin{tabular}{|l|l|l|}
\hline Nilai Kualitatif & Persentase & Jumlah siswa \\
\hline SB & 0 & 0 \\
\hline B & $82,76 \%$ & 24 \\
\hline C & $17,24 \%$ & 4 \\
\hline K & 0 & 0 \\
\hline
\end{tabular}

Penilaian kinerja presentasi dinilai dari aspek kreativitas kelompok, kebenaran substansi materi, bagaimana dalam penyajian materi dan grafis presentasi. Sehingga diperoleh nilai kategori Baik terdapat 25 siswa dengan perolehan persentase $82,76 \%$. Kemudian untuk nilai dalam kategori Cukup diperoleh 4 siswa dengan persentase 17,24\%. Untuk nilai kategori Sangat Baik dan Kurang tidak didapat siswa.

Tabel 6. Persentase Pencapaian KKM Kinerja Presentasi Siswa Kelas XI APHP 2

\begin{tabular}{|l|l|}
\hline Jumlah Siswa & 29 \\
\hline Siswa yang belum tuntas & 5 \\
\hline Siswa yang sudah tuntas & 24 \\
\hline Presentase belum tuntas & $17,24 \%$ \\
\hline Presentase sudah tuntas & $82,76 \%$ \\
\hline
\end{tabular}

Dilihat dari persentase pencapaian kriteria ketuntasan dalam kinerja presentase diperoleh sebanyak 5 siswa belum mencapai ketuntasan dalam nilai persentase $17,24 \%$. Sedangkan siswa yang memenuhi kriteria ketuntasan dalam kinerja presentasi sebanyak 24 siswa dalam persentase $82,76 \%$.

Hasil menunjukkan bahwa sebagian siswa belum menunjukkan hasil yang maksimal, sehingga perlu dilakukan tindakann siklus II.

\section{Tabel 7. Penilaian Rata-rata Kelas Motivasi Belajar Siklus II Siswa Kelas XI APHP 2}

\begin{tabular}{|l|l|l|l|}
\hline \multirow{2}{*}{ No } & Indikator & Nilai \\
\cline { 2 - 4 } & Rata-rata & Predikat \\
\hline 1 & Selalu hadir dan tidak pernah membolos sekolah & 2.69 & B \\
\hline 2 & $\begin{array}{l}\text { Serius pada saat mengikuti kegiatan pembelajaran } \\
\text { dengan }\end{array}$ & 2.86 & B \\
\hline \multirow{2}{*}{3} & $\begin{array}{l}\text { Aktif bertanya serta mengajukan pendapat secara runtut } \\
\text { dengan bahasa vang baik dan benar }\end{array}$ & 2.66 & B \\
\hline \multirow{2}{*}{4} & $\begin{array}{l}\text { Melaksanakan tugas individu, kelompok dengan baik } \\
\text { dan }\end{array}$ & 2.69 & B \\
\hline \multirow{2}{*}{5} & $\begin{array}{l}\text { Mampu mempertahankan pendapat dari permasalahan } \\
\text { materi pembelaiaran }\end{array}$ & 2.72 & B \\
\hline \multirow{2}{*}{6} & $\begin{array}{l}\text { Selalu cepat dalam merespon atau menanggapi materi } \\
\text { pembelaiaran vang disaiikan }\end{array}$ & 2.72 & B \\
\hline \multirow{2}{*}{\begin{tabular}{l} 
JUMLAH \\
\cline { 2 - 4 }
\end{tabular}} & Rata-rata & 16.34 & 2.72 \\
\hline
\end{tabular}

Dari hasil observasi terhadap motivasi belajar siswa Rekayasa Perangkat Lunak 1 siklus II diperoleh rata-rata kelas aspek penilaian ketekunan diperoleh nilai rata-rata kelas dalah 2.72 Dari ke-enam indikator diperoleh dengan predikat B (Baik), secara keseluruhan motivasi belajar kelas XI APHP 2 meningkat dibandingkan dengan motivasi belajar pada siklus I. 
Vol 1. No 1. Agustus 2021, e-ISSN : 2807-1808 | P-ISSN : 2807-2294

Tabel 8. Penilaian Uji Kompetensi II Siswa Kelas XI APHP 2

\begin{tabular}{|l|l|}
\hline Jumlah peserta didik & 29 \\
\hline Skor tertinggi & 100 \\
\hline Skor terendah & 72 \\
\hline Memenuhi kompetensi & 24 \\
\hline Belum memenuhi kompetensi & 5 \\
\hline Persentase memenuhi kompetensi & $82,76 \%$ \\
\hline Persentase belum memenuhi kompetensi & $17,24 \%$ \\
\hline
\end{tabular}

Dari hasil tes uji kompetensi II yang merupakan perbaikan dari uji kompetensi I diperoleh data sebanyak 24 siswa atau 82,76\% sudah masuk kategori memenuhi kompetensi, sedangkan 5 siswa atau 17,24\% masih belum memenuhi standar kompetensi.

\section{SIKLUS III}

Penerapan pembelajaran PPKn pada siklus III melalui pembelajaran tipe Group Investigation adalah:

\section{1) Perencanaan Tindakan Siklus III}

Sebelum mengawali pelaksanaan tindakan pada siklus III, peneliti dan guru secara kolaboratif menyusun perbaikan rancangan kegiatan dengan mengadakan diskusi tentang rancangan pembelajaran dengan metode Group Investigation. Dengan memotivasi belajar siswa untuk lebih bersikap aktif dalam pembelajaran. Menyusun rancangan pembelajaran dengan metode Group Investigation. Menetapkan dan menyusun deskriptor dan indikator seabagai kriteria untuk mengukur keberhasilan pembelajaran PPKn dengan menyiapkan uji kompetensi III terhadap siswa bersama kunci jawaban. Tahap perencanaan dimulai dengan membuat Rencana Pelaksanaan Pembelajaran (RPP) PPKn dan model pembelajaran kooperatif tipe Group Investigation materi pokok Bahtera Keadilan Bangsa Indonesia. Menyiapkan lembar penilaian uji kompetensi siswa, mencatat hasil pengamatan di lapangan, menyiapkan lembar penilaian motivasi belajar dan dokumentasi. Siswa mengumpulkan tugas yang dilakukan secara individu.

Adapun perbaikan rancangan untuk siklus III yaitu guru harus lebih memaksimalkan cara menyampaikan langkah-langkah dalam metode Group Investigation, guru harus kembali menyampaikan contoh-contoh konkret dalam pembelajaran PPKn. Guru membangun interaksi dengan siswa lebih baik dan memacu motivasi siswa untuk lebih semangat belajar. Membimbing dan memberi arahan saat proses pembelajaran berlangsung.

\section{2) Pelaksanaan Tindakan Siklus III}

Pelaksanaan tindakan pembelajaran yang dilakukan pada siklus III sama halnya dengan tindakan pembelajaran siklus I dan II. Adapun kegiatan ini dilaksanakan pada hari Senin, tanggal 9 dan 16 Agustus 2020. Dalam pelaksanaan ini guru sebagai pelaku tindakan pembelajaran di kelas dan peneliti merekam dan mencatat proses kegiatan. Tindakan siklus III di alokasikan selama 2x45 menit dengan menggunakan materi yang sama dengan siklus I dan II. Mengadakan uji kompetensi III diakhir pertemuan, dengan maksud untuk memperoleh hasil sejauh mana siswa memahami pembelajaran atau evaluasi belajar pada Bab V ini. Di akhir pertemuan peneliti meminta siswa mengumpulkan tugas individu yang telah dikerjakan di rumah.

\section{3) Observasi dan Interpretasi siklus III}

Kegiatan pengamatan terhadap tindakan pembelajaran dilakukan saat berlangsungnya kegiatan pembelajaran. Dari hasil pengamatan proses pembelajaran dengan metode Group Investigation sudah menunjukkan kemampuan siswa dalam bersikap. Secara keseluruhan siswa mampu mengikuti pembelajaran yang telah dirancang. Walaupun masih beberapa siswa yang masih bersikap pasif selama proses pembelajaran. Observasi terhadap motivasi belajar pada siklus III mengalami peningkatan sama halnya dalam hasil uji kompetensi III. 


\section{4) Analisis dan Refleksi Tindakan Siklus III}

Pelaksanaan kegiatan refleksi dan evaluasi menunjukkan dari siklus I dan siklus II, siswa sudah mengalami peningkatan dalam hal perubahan sikap dan motivasi belajar. Dan dilihat dari proses pembelajaran yang semula tidak kondusif bisa menjadi suasana yang menyenangkan. Motivasi belajar mejadi berkembang, kesadaran akan bersikap juga ditunjukkan siswa menjadi lebih baik.

Tabel 9. Penilaian Rata-rata Kelas Motivasi Belajar Siklus III Siswa Kelas XI APHP 2

\begin{tabular}{|c|c|c|c|}
\hline \multirow[b]{2}{*}{ No } & \multirow[b]{2}{*}{ Indikator } & \multicolumn{2}{|l|}{ Nilai } \\
\hline & & Rata-rata & Predikat \\
\hline 1 & Selalu hadir dan tidak pernah membolos sekolah & 2.83 & $B$ \\
\hline 2 & $\begin{array}{l}\text { Serius pada saat mengikuti kegiatan pembelajaran } \\
\text { dengan baik }\end{array}$ & 2.93 & $\mathrm{~B}$ \\
\hline 3 & $\begin{array}{l}\text { Aktif bertanya serta mengajukan pendapat secar } \\
\text { runtut dengan bahasa yang baik dan benar }\end{array}$ & 2.66 & B \\
\hline 4 & $\begin{array}{l}\text { Melaksanakan tugas individu, kelompok dengan baik } \\
\text { dan benar }\end{array}$ & 2.66 & $\mathrm{~B}$ \\
\hline 5 & $\begin{array}{lll}\text { Mampu mempertahankan pendapat dar } \\
\text { permasalahan materi pembelajaran }\end{array}$ & 2.97 & B \\
\hline 6 & $\begin{array}{l}\text { Selalu cepat dalam merespon atau menanggapi mater } \\
\text { pembelajaran yang disajikan }\end{array}$ & 2.9 & B \\
\hline & JUMLAH & 16.95 & \\
\hline & Rata-rata & 2.83 & B \\
\hline
\end{tabular}

Dari hasil observasi terhadap motivasi belajar siswa Rekayasa Perangkat Lunak 1 siklus III diperoleh rata-rata kelas dari ke-enam indikator adalah 2.83 dengan predikat B (Baik). Penilaian motivasi belajar pada siklus III ini diperoleh hasil adanya peningkatan motivasi belajar siswa Kelas XI APHP 2 siswa mendapat nilai yang memenuhi kompetensi dari aspek indikator motivasi belajar. Sehingga proses pembelajaran menggunakan metode Group Investigation berhasil diterapkan pada kelas XI APHP 2. Satu siswa belum memenuhi kompetensi karena absen sakit.

Tabel 10. Penilaian Uji Kompetensi III Siswa Kelas XI APHP 2

\begin{tabular}{|l|l|}
\hline Jumlah siswa & 29 \\
\hline Skor tertinggi & 95 \\
\hline Skor terendah & 75 \\
\hline Memenuhi kompetensi & 28 \\
\hline Belum memenuhi kompetensi & 0 \\
\hline Persentase memenuhi kompetensi & $96,55 \%$ \\
\hline Persentase belum memenuhi kompetensi & $3,45 \%$ \\
\hline
\end{tabular}

Di akhir proses pembelajaran dilakukan uji kompentensi dengan tujuan melihat sejauh mana siswa memahami pembelajaran dengan menggunakan metode Group Investigation. Maka diperoleh siswa yang memenuhi kriteria ketuntasan sebanyak 28 siswa atau 96,55\%. Dan sebanyak 1 siswa belum memenuhi kriteria ketuntasan, dalam persen dinyatakan 3,45\%. Satu siswa tersebut selama proses kegiatan pembelajaran yang dilakukan oleh peneliti tidak dapat mengikuti, dikarenakan absen sakit. 
Vol 1. No 1. Agustus 2021, e-ISSN : 2807-1808 | P-ISSN : 2807-2294

\begin{tabular}{|l|l|}
\hline Jumlah siswa & 29 \\
\hline Memenuhi kompetensi & 6 \\
\hline Belum memenuhi kompetensi & 23 \\
\hline Persentase memenuhi kompetensi & $20,69 \%$ \\
\hline Persentase belum memenuhi kompetensi & $79,31 \%$ \\
\hline
\end{tabular}

Dilihat dari hasil tabel, diperoleh hasil siswa masih banyak yang belum mengumpulkan tugas. Hal ini disebabkan karena siswa masih belum disiplin dan bertanggung jawab. Dari 29 siswa hanya6 atau 20,69\% orang siswa yang mengumpulkan tugas individu.

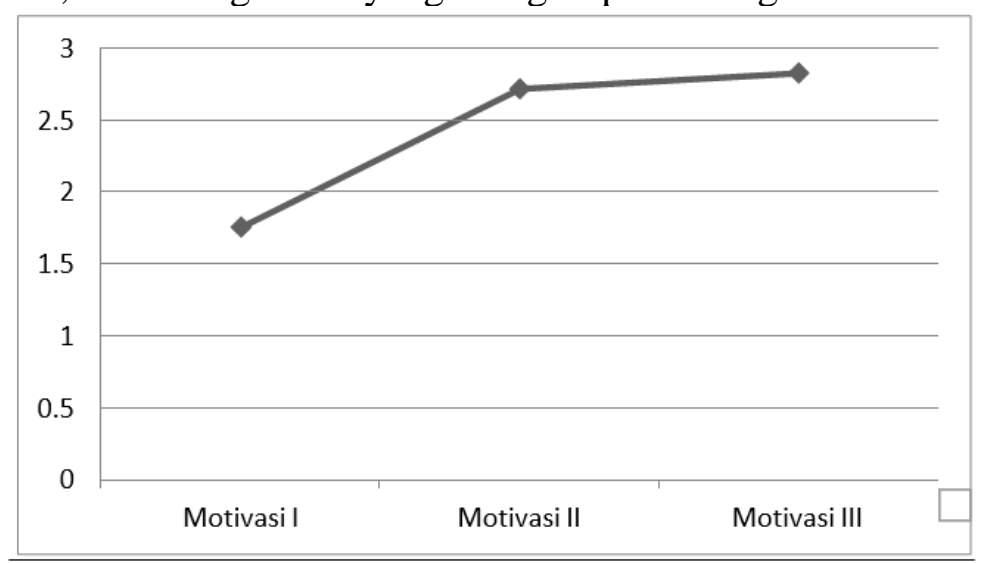

\section{Gambar 1. Grafik Nilai Rata-rata Penilaian Motivasi Tiga Siklus Kelas XI APHP 2}

Pada grafik penilaian motivasi belajar siswa kelas XI APHP 2 diperoleh adanya peningkatan hasil rata-rata kelas dari siklus I sampai siklus III terhadap peningkatan motivasi belajar siswa. Peningkatan dari nilai rata-rata 1.67 pada siklus I, 2.72 pada siklus II dan 2.83 pada siklus III.

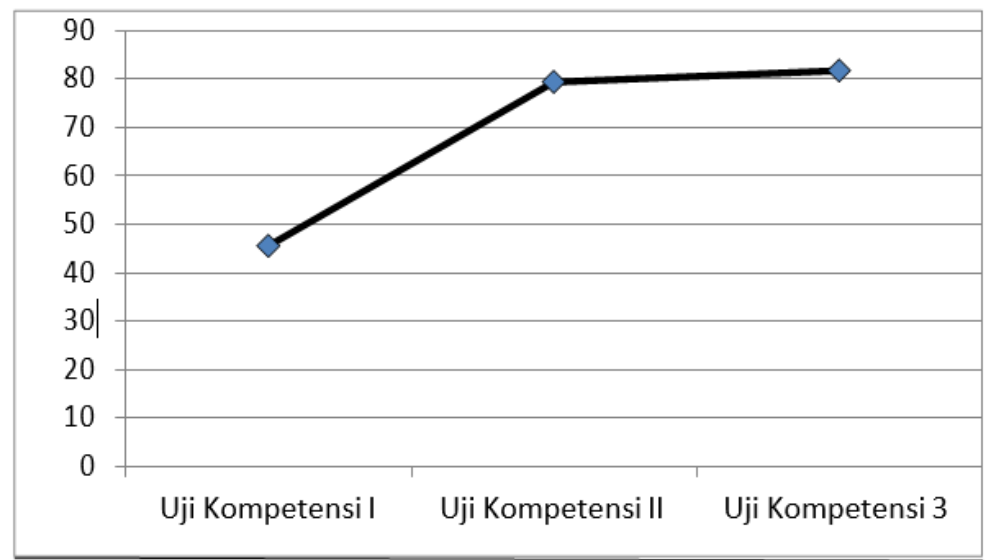

\section{Gambar 2. Grafik Nilai Rata-rata Uji Kompetensi Siswa Kelas XI APHP 2}

Dari grafik rata-rata nilai uji kompetensi pada siklus I, siklus II, dan siklus III diperoleh adanya kenaikan nilai rata-rata siswa dalam nilai yang bersifat kuantitatif. Peningkatan dari siklus I yang mendapat nilai rata-rata 45.52, siklus II 79.41, dan 81.75 untuk siklus III. Hal ini menunjukan metode Group Investigation berpengaruh baik terhadap nilai hasil uji kompetensi siswa.

Hasil pembelajaran tersebut menunjukkan bahwa secara penilaian sikap spiritual dan sikap sosial, uji kompetensi siswa dan motivasi belajar siswa sudah memenuhi ketuntasan sehingga penelitian dihentikan.

Dari kebanyakan anak-anak Indonesia ternyata hanya mampu menguasai $30 \%$ materi bacaan dan mereka sulit sekali menjawab soal-soal berbentuk uraian yang memerlukan penalaran. Hal ini mungkin karena mereka sangat terbiasa untuk menghafal dan mengerjakan 
pilihan ganda. Ini dapat dilihat dari pengamatan dalam uji kompetensi, hasilnya diperoleh masih banyak yang belum tuntas belajar pada uji kompetensi I. Jawaban yang harusnya berupa uraian hanya dijawab dengan singkat tanpa penjelasan yang lebih. Tampaknya siswa masih belum mengembangkan pemikirannya tehadap soal-soal penalaran yang berupa uraian. Pada uji kompetensi II yang merupakan perbaikan uji kompetensi I, hasilnya mengalami peningkatan. Siswa sudah mampu memberikan jawaban yang lebih baik daripada yang sebelumnya. Dan pada uji kompetensi III pada siklus III diperoleh 28 siswa sudah memenuhi standar ketuntasan minimal. Peningkatan hasil prestasi belajar ini menandakan bahwa pembelajaran menggunakan metode Group Investigation berhasil.

\section{KESIMPULAN} berikut:

Berdasarkan hasil penelitian dan pembahasan, maka dapat diambil kesimpulan sebagai

1. Penggunaan metode Group Investigation, secara signifikan mempengaruhi motivasi belajar siswa kelas X Rekayasa Perangkat Lunak 1 menjadi meningkat, dilihat dari nilai rata-rata secara kualitatif Siklus I 1.76, siklus II 2.72, dan pada siklus III 2.83.

2. Penggunaan metode Group Investigation, secara signifikan mempengaruhi prestasi belajar siswa kelas X Rekayasa Perangkat Lunak 1 menjadi meningkat, dilihat dari hasil rata-rata kelas uji kompetensi Siklus I dengan rata-rata 45.52, Siklus II 79.41, dan pada siklus III 81.75.

\section{DAFTAR PUSTAKA}

Arikunto, Suharsimi. (2006). Prosedur Penelitian Suatu Pendekatan Praktik, Edisi Revisi VI. Jakarta: PT Rineka Cipta.

Arikunto, Suharsimi. . (2010). Prosedur Penelitian Suatu Pendekatan Praktik, Edisi Revisi 2010. Jakarta: PT Rineka Cipta

Cholisin. (2004). Diktat Pendidikan Kewarganegaraan (Civic education). Yogyakarta: UNY Press.

Departemen Pendidikan Dan Kebudayaan. (1995). Kamus Besar Bahasa Indonesia. Jakarta: Balai Pustaka.

Departemen Pendidikan Nasional. (2004). Undang-undang Republik Indonesia Nomor 20 Tahun 2003 Tentang Sistem Pendidikan Nasional. Pusat Data dan Informasi Pendidikan, Balitbang.

Djamarah. (2002). Teori Motivasi, Edisi 2. Jakarta : PT. Bumi Aksara

Hadi, Sutrisno. (1994). Metodologi Research Jilid I. Yogyakarta: Andi Offset.

Hamalik, Oemar. (2004). Psikologi Belajar dan Mengajar. Bandung: Sinar Baru Algensindo.

Hariwijaya. (2007). Metodologi dan Teknik Penulisan Skripsi, Tesis, dan Disertasi: Untuk Ilmu-Ilmu Sosial dan Humaniora. Yogyakarta: Elmatera Publishing.

Hasan, S., Rakhman, M., dan Ardiana, H. (2011). Model Cooperativelearning Tipe Group Investigation Untuk Meningkatkan Hasil Belajar Pada Mata Pelajaran Perawatan Dan Perbaikan System Refrigerasi. Invotec VII (2). Hlm. 189-198.

Kartono, Kartini. (2009). Pengantar Metodologi Riset Sosial. Bandung: Mandar Maju

Kementrian Pendidikan dan Kebudayaan. (2012). Bahan Uji Publik Kurikulum 2013.Jakarta: Kementrian Pendidikan dan Kebudayaan.

Kementerian Pendidikan dan Kebudayaan. (2014). Buku Guru Pendidikan Pancasila dan Kewarganegaraan Untuk SMA/MA/SMK/MAK Kelas X. Jakarta

Kiswoyowati, Amin. (2011). Pengaruh Motivasi Belajar Dan Kegiatan Belajar Siswa Terhadap Kecakapan Hidup Siswa. Jurnal ISSN (1). Hlm. 120-126.

Maimunah. (2005). Pembelajaran Volume Bola dengan Belajar Kooperatif Model GI pada Siswa Kelas X SMA Laboratorium UM. Tesis tidak diterbitkan. Malang: Pascasarjana Universitas Negeri Malang. 
Moleong, Lexy J. (2007). Metode Penelitian Kualitatif. Bandung: Remaja Rosda Karya.

Love, A., \& Kruger, A.C. (2005). Teacher Beliefs and Student Achievement in Urban Schools Serving African American Students. The Journal of Educational Research 99 (2). Hlm. 87- 98.

Nikmah, Astin. (2013). Dampak Penggunaan Handphone Terhadap Prestasi Siswa. Ejurnal Dinas Pendidikan Kota Surabaya 5. Hlm.1-8.

Nurkancana dan Sunartana. (1986). Evaluasi Pendidikan. Surabaya: Usaha Nasional.

Ratam. (2009). Pengaruh Pola Pembelajaran Aktif, Kreatif, Efektif Dan Menyenangkan (PAKEM) Dan Motivasi Belajar Terhadap Ketuntasan Belajar IPS Materi Sejarah Siswa Sekolah Dasar Kecamatan Karanganyar Kabupaten Purbalingga. Tesis. Surakarta: Universitas Sebelas Maret.

Roida, E.F.S. (2013). Pengaruh minat dan kebiasaan belajar siswa terhadap prestasi belajar matematika. Jurnal Formatif 2(2). Hlm.122-131.

Rusli, Ratna Sayekti. (1988). Tes dan Pengukuran Dalam Pendidikan, Jakarta: Departemen Pendidikan dan Kebudayaan.

Samsuri. (2010a). Transformasi Gagagan Masyarakat Kewargaan (Civil Society) Melalui Reformasi Pendidikan Kewarganegaraan di Indonesia (Studi Pengembangan Kebijakan Pendidikan Kewarganegaraan pada Pendidikan Dasar dan Menengah Era Reformasi). Disertasi. Pascasarjana Universitas Pendidikan lndonesia. Bandung. Samsuri. (2010b). Model Pembelajaran Pendidikan Kewarganegaraan untuk Membangun Kompetensi Warga Negara. Civicus. Hlm. 37-48.

Sanjaya, Wina. (2006). Strategi Pembelajaran. Jakarta: Prenada Media Group.

Sardiman, A.M. (2006). Interaksi dan Motivasi Belajar Mengajar. Jakarta : PT. Raja Grafindo Persada

Sardiman, A.M. (2011). Interaksi dan Motivasi Belajar Mengajar. Jakarta: Rajawali.

Slameto. (2003). Belajar dan Faktor-Faktor yang Mempengaruhinya. Jakarta: PT. Rineka Cipta.

Slavin, Robert E. (2003). Educational Psychology: Theory and Practice, 7thEdition. Boston: John Hopkins University

Sudijono, Anas. (2005). Pengantar Evaluasi Pendidikan. Jakarta: Raja Grafindo Persada.

Sudjana, Nana. (1992). Penelitian Hasil Proses Belajar - Mengajar. Bandung: Remaja Rosdakarya.

Sudjana, Nana. (2005). Penilaian Hasil Proses Belajar Mengajar. Bandung: Remaja Rosdakarya

Sugiyono. (2006). Statistika Untuk Penelitian, Cetakan Ketujuh, Bandung: Alfabeta.

Sugiyono. (2009). Metode Penelitian Kualitatif, Kuantitatif, dan R\&D. Bandung: Alfabeta

Sutama. (2010). Metode Penelitian Pendidikan Cetakan Pertama. Surakarta: Fairuz Media.

Tsoi, M. F., Goh, N. K. \& Chia, L. S. (2004). Using Group Investigation for Chemistry in Teacher Education. Asia-Pacific Forum on Science Learning and Teaching, Volume 5. Issue 1, Article 6.

Trianto. (2007). Model-model Pembelajaran Inovatif Berorientasi Konstruktivistik. Jakarta: Prestasi Pustaka.

Wahab. A,. Azis. (1999). Kurikulum PPKn Tahun 1994: Isu dan Permasalahan untuk Penyempurnaan. Jurnal Pendidikan dan Kebudayaaan 5. Hlm. 49-59.

Winataputra. (1992). Teori Belajar dan Model-model Pembelajaran. Jakarta: PAUPPAI Universitas Terbuka.

Wiraatamajda, Rochiati. (2006). Metode Penelitian Tindakan Kelas. Bandung: Rosdakarya. 